Mirjana M. Kovač

UDK 811.111'342.9:378(497.5)

University of Split,

DOI: $10.4312 /$ vestnik.11.87-102

Faculty of Humanities and Social Sciences

Croatia

mirjana@ffst.hr

Gloria Vickov

University of Split,

Faculty of Humanities and Social Sciences

Croatia

gvickov@ffst.hr

\title{
THE INFLUENCE OF PRE-TASK PLANNING ON SPEED AND BREAKDOWN FLUENCY
}

Previous research considers two principal types of task-based planning that are distinguished in terms of when the planning takes place, i.e. pre-task planning and within-task planning (Ellis 2005). The former occurs before the task has been performed, while within-task planning occurs during its performance.

The focus of this study is pre-task planning, which has proven to be a rich vein for empirical study and attracted considerable interest among researchers over the past few decades. There are various definitions of what a task actually is. Based on an action-oriented approach, the Common European Framework of Reference for Languages (CEFR 2001: 10) considers a task within a wider social context and defines it as "any purposeful action considered by an individual as necessary in order to achieve a given result in the context of a problem to be solved, an obligation to fulfil or an objective to be achieved". Being defined in this way, tasks refer to actions which are not exclusively language-related even though they involve language activities and make demands upon the individual's communicative competence (e.g. moving a wardrobe, writing a book, ordering a meal in a restaurant etc.). However, the broadly adopted definition among researchers determines a task as "an activity which requires learners to use language, with emphasis on meaning, to attain an objective" (Bygate et al. 2001: 11). Numerous studies have already shown the favourable impact of pre-task planning on the overall discourse quality in L2 (e.g. Foster and Skehan 1996; Ortega 1999; Wendel 1997; Yuan and Ellis 2003; Götz 2013). Moreover, pre-task planning has been acknowledged as a significant process in 
task-based language teaching, where the tasks based on the theories of speech production are constructed to measure L2 cognitive abilities.

Pre-task planning usually involves focused or unfocused instructions being given to learners to help them plan before task performance (e.g. Foster and Skehan 1996; Ellis 2005). The opportunity to plan before speaking provides the learners with some time to test their own capabilities and maximize the use of their existing linguistic repertoire, which is often insufficiently active and thus prone to loss.

In a comprehensive synthesis of the previous research, Suzuki (2017: 10-11) compares a number of quantitative studies conducted between 1995 and 2016. The author investigates over 200 quantitative studies relevant to pre-task planning based on the six criteria: a) the study is published between 1995 and 2016; b) the study is experimental in nature, aiming to explore the impact of pre-task planning on L2 learners' task performance; c) the study measures oral variables through the comparison of identical participants' performance across different conditions; d) the participants in the study are L2 or foreign language learners aged 18 years or older; e) the tasks in the study are monologic or dyadic oral communication tasks; and f) the study thoroughly describes the characteristics of pre-task planning (e.g. guided or unguided, length of planning time, type of planning) and main tasks (e.g. task complexity). However, some studies have been excluded from the comparison because of the following reasons: a) the study is a review of past studies, without new empirical data; b) the study analyses data from reports that are already included in the synthesis; c) the study is based on performance scores marked by raters; d) the study uses a descriptive research design; and e) that study includes additional treatment or instructions given during the main tasks. Suzuki points out that this range of studies demonstrates that there are numerous ways to assess the learners' oral performance, for this reason, only 40 out of 200 are taken for comparison. In his view, one of the reasons for the inconsistent results may also be due to the different approaches in measuring various aspects of performance.

Fluency is, unlike other elements referring to the learners' interlanguage knowledge, i.e. complexity and accuracy, a performance phenomenon, pointing to the efficient, smooth and unproblematic ongoing psycholinguistic processes of speech production. Due to the different understandings of the concept, researchers have proposed various ways of measuring verbal fluency, sharing the view that fluency is an important skill to be evaluated in second language testing. It can be associated with objective temporal variables such as speech rate, mean length of runs, phonation-time ratio, articulation rate, silent pauses and the like (e. g. Kormos and Dénes 2004; Prefontaine 2010).

According to Lennon (1990), fluency can be viewed as broad or narrow. Broad fluency can be regarded as general language proficiency, whereas narrow fluency is solely a temporal phenomenon. Segalowitz (2010) distinguishes among three aspects of L2 fluency: utterance, cognitive and perceived fluency. Firstly, L2 utterance fluency includes temporal speech variables indicating the operation of the underlying cognitive processes. 
Thus, utterance fluency is described by the variables which are the result of the pressure caused by planning in real time. As such, it can be objectively defined by measuring temporal aspects of the speech samples (de Jong et al. 2013). Secondly, L2 cognitive fluency refers to the fluid operation of the cognitive processes responsible for L2 production, i.e. a nearly simultaneous execution of the underlying processes involved in speech production (Segalowitz 2010). Contrary to this definition, which describes fluency in terms of skill performance, perceived fluency is defined as "an impression on the listener's part that the psycholinguistic processes of speech planning and speech production are functioning easily and efficiently" (Lennon 1990: 391). A similar distinction made between utterance and cognitive fluency, as proposed by Segalowitz (2010), is adopted by Požgaj Hadži et. al. (2012), who assume that fluency refers to the learner's control over the linguistic knowledge, which is reflected in the speed and ease of retrieving relevant information in real time. Finally, Götz (2013) introduces another vital concept of fluency, including nonverbal behaviour as an important criterion in measuring it.

To date, most of the studies have examined utterance fluency according to three different aspects, i.e. speed fluency, breakdown fluency, and repair fluency (Tavakoli and Skehan 2005; Skehan 2003). Speed fluency generally refers to the speed with which speech is delivered and can be measured by calculating the speech rate, such as the number of syllables per second. Breakdown fluency examines the ongoing speech flow and is usually measured by counting the number and length of filled and unfilled pauses. Repair fluency measures how often learners make repetitions in their speech, false starts, self-repairs (Kovač and Milatović 2013) and the like.

A number of studies investigate variables which might be regarded as good fluency predictors, i.e. which aim to find out the relationship between utterance fluency and perceived fluency. De Jong et al. (2011) report that despite the differences in investigated measures used across different studies, the majority report that some temporal measures are connected with a good perception of fluency. For instance, Kormos and Dénes (2004) conclude that not only the speech rate but also the mean length of runs, phonation-time ratio, and the number of stressed words per minute are the best predictors of fluency. The authors emphasize that the articulation rate should not necessarily be identified with fluency. In their view, fluency is about pausing at the right places. Other researchers (e.g. Lennon 1990; Riggenbach 1991; Freed 2000) also indicate that these sets of variables are good fluency predictors. In an extensive study, De Jong et al. (2013) try to identify the measures of utterance fluency that are indicators of L2 cognitive fluency, and discover that some measures of utterance fluency cannot be regarded as indicators of L2 cognitive fluency, such as the mean duration of silent pauses. Cucchiarini et al. (2002) rate experts' opinions concerning perceived fluency, and the strongest correlation is found between their ratings and the speech rate as well as the mean length of runs, whereas other temporal parameters, such as articulation rate, phonation-time ratio, number and duration of pauses, result in lower values of the correlation coefficient. 
Prefontaine (2010) investigates the viability of using a computer programme to automatically measure temporal variables of utterance fluency for language evaluation purposes. She emphasizes that fluency research using the PRAAT script to detect pauses and syllables automatically is relatively new. This work follows the work of De Jong et al. (2007), who investigate the impact of task complexity on L1 and L2 Dutch speaking performance, using the PRAAT software to measure the phonation time ratio and syllables per second. However, in Prefontaine's study PRAAT is used to measure other temporal variables of fluency as well. Her idea is not new, but it represents one of the first attempts to use automatic speech rate measurements to assess tasks designed for language evaluation. An important conclusion is that the obtained results point to a strong connection between the PRAAT temporal fluency measurements and perceived fluency based on the raters' interpretation of data.

However, the findings on the influence of pre-task planning on accuracy, complexity and fluency yield mixed results, due to various factors such as task type, the kind of instructions given prior to planning, learner proficiency and age, length of planning time, etc. For instance, as observed by Ortega (2005), surveys conducted in different countries and different contexts show that adult speakers produce more fluent and complex speech if they have time to plan the utterance before speaking. In her study, the respondents often emphasize the benefit that planning time enables them to organize their thoughts and identify any potential linguistic difficulties in advance. However, the greatest benefit of pre-task planning as a problem solving activity is reflected in the greater possibility of retrieving lexical items from the mental lexicon and solving lexical difficulties.

According to Foster (1996), Foster and Skehan (1996), Wendel (1997), Ortega (1999), Skehan and Foster (1997), pre-task planning leads to increased fluency, i.e. the speech rate increases and the occurrence of different forms of disfluent speech decreases. Foster (2001) also records a positive impact of pre-task planning on the temporal fluency variables, especially the increased number of words per minute. However, the authors emphasize that the beneficial effects of pre-task planning are mostly connected with cognitively complex tasks such as decision-making tasks and difficult narratives. According to Robinson (2011), planning simplifies the task so that the speaker can reduce the amount of attention to the grammatical form and focus more on the automated approach to stored knowledge, resulting in greater fluency. In another study, referring to Kormos (2006), conscious awareness and working memory capacity are limited, hence some factors, such as the possibility to plan the task, may mitigate the processing requirements at certain levels of speech production and positively affect overall speech performance.

Kawauchi (2005: 162) investigates the correlation between language proficiency and pre-task planning. In his view, advanced speakers benefit the least from planning because they have obviously reached a "ceiling point", assuming that their L2 knowledge is sufficiently proceduralized, which makes it easier for them to retrieve the required lexical units and grammatical forms under the constraints of time pressure. 
Notably, a vital aspect is the amount of time required to plan a speech task, and consequently the existence of correlations between fluent speech and planning time. Mehnert (1998) conducts research in which three groups of subjects are provided with one, five, ten, and zero minutes for planning. The most significant difference is observed between the speakers without any planning time and those who get only a few minutes to plan their performance. Mehnert establishes that a shorter planning time exhibits the same effect as longer planning time.

With respect to guided or unguided planning, Foster and Skehan (1996) investigate the impact of directed planning, i.e. the effects of planning where the subjects are advised on how to pay attention to the content, syntax, and lexis. Interestingly, the effect of directed and guided planning points to a positive impact on fluency in the case of narrative tasks, but not other task types.

As cited before, in an overview of the existing pre-task planning studies, Suzuki (2017) reveals that at the present stage of research a relatively small number of task and planning variables have been investigated in a consistent way. For instance, a comparison of the data reveals that tasks tend to be monologic, asking participants to retell a story based on series of pictures, and that most studies are unguided, requiring participants to take notes. Ellis (2009) emphasizes that note-taking is a very common practice, yet the shortcoming is that the notes do not reveal what participants actually do during the planning time.

Finally, the task type plays a major role for L2 skill development and therefore must be designed carefully in order to trigger all or just certain aspects of speech performance, i.e. speech accuracy, language complexity, and fluency. In general, theories explaining speech production in L2 emphasize the necessity of introducing speech tasks (e.g. narratives, instructions, decision-making, opinion-giving, personal information, etc.) and different performance conditions (e.g. unguided, guided, teacher-led planning, within-task planning, etc.) into curricula based on Levelt's model of speech production (e.g. Bygate and Samuda 2005; Kormos 2006; Skehan 2009; Skehan et al. 2012; Kovač 2016; Suzuki 2017). In addition, monitoring, which is often neglected in many L2 curricula, should assume a central position in language teaching since it is involved in almost every level of speech production, which directly influences the quality of speech performance.

Taking into consideration the fact that the studies in the field have so far resulted in contradictory findings, we have conducted research aimed at shedding additional light on determining the relationship between pre-task planning and speech fluency. The study described below is an attempt to find out whether the planning stage significantly enhances speech fluency by investigating speed and breakdown fluency. The present findings are thus expected to extend the current knowledge about the influence of planning on EFL learners' speech fluency.

The following hypothesis is formulated: 
Pre-task planning will result in greater fluency, being reflected in fewer and shorter pauses as well as in an increased speech and articulation rate compared to speech produced without pre-task planning.

The research design of the study and the results are outlined in the following sections. The paper ends with pedagogical implications and concluding remarks, which also opens new avenues for further research.

\section{THE PRESENT STUDY}

\subsection{Participants}

Our participants were a total of seventy-four Croatian EFL learners (first-year students of electrical engineering). The study was conducted in the academic year 2016/2017 at the Faculty of Electrical Engineering, Mechanical Engineering and Naval Architecture at the University of Split. These students were selected according to their English Matura Exam results (the State Matura Exam is a secondary school-leaving examination in Croatia). According to an interview which preceded the recordings, all the participants scored excellent or very good grades in the English State Matura Exam at the highest level (A level). Also, all of them had had a similar language learning history, namely, all of them had learned English at primary school and grammar school, for at least nine years. None of them had spent more than ten days in an English-speaking country.

\subsection{Instruments, procedure and analysis}

The participants were divided into two groups and instructed to respond to a narrative speech task including a picture description. The cartoon was taken from a popular English course book which has already been used in similar research (e.g. Kormos and Dénes 2004; Riazantseva 2001). The description consisted of six pictures which were chronologically ordered. The story was highly structured, with a clear beginning, middle part and predictable ending. The content of the story was familiar to the participants and the vocabulary contained high frequency words and frequent, formulaic expressions. The pictures depicted two people meeting in a park, talking to each other, spending some time together, and eventually getting married. The participants were asked to shape the story based on the presented pictures. They were advised to make at least four sentences for each picture and to include their views, comments, previous experiences, anything that might make the story more interesting and more informative for the listener. They were not time constrained.

One group of 37 participants was provided with 10 minutes for planning, whereas the other group of 37 participants was given no planning time at all and were asked to 
start speaking immediately upon seeing the pictures. The recordings were conducted in an office at the Faculty.

As to the temporal fluency variables, these were extracted by means of the PRAAT speech analysis program in order to be automatically measured for evaluation purposes. In the present study, the following automatically quantifiable speed (a, b) and breakdown (c, d) fluency performance variables are taken into account:

a) The unpruned speech rate is expressed as the total number of produced syllables over the total duration (including pauses) expressed in seconds, including repetitions, false starts, self-repairs, and filled pauses;

b) The articulation rate refers to the speed of speaking and is calculated as the total number of produced syllables over the total speaking time when producing the speech sample (Kormos and Dénes 2004);

c) The average pause duration is expressed by dividing the total length of unfilled pauses above 0.25 seconds by the total number of unfilled pauses above 0.25 seconds (Kormos and Dénes 2004); and

d) the number of unfilled pauses per minute.

Speech rate is found to be one of the most important variables in L2 fluency (Lennon 1990; Riggenbach 1991; Cucchiarini et al. 2002; Kormos and Dénes 2004). Also, Cucchiarini et al. (2002: 2863) point out that speech rate is an excellent predictor of perceived fluency, because it combines the articulation rate (speed) and the number of pauses speakers make. Götz (2013) implies that there is a strong correlation between fluent speech and the number, distribution, duration and function of pauses.

As already stated, the statistical analysis is performed under two different task conditions, i.e. with and without planning time.

\section{3}

\section{RESULTS}

The statistical analysis results related to all considered temporal variables are shown in Tables 1 to 4 . Each table depicts the values of the sample mean and variance based on a sample of 37 subjects, the planning and non-planning groups, respectively. Before the application of a suitable test, it is necessary to verify the prerequisites of the normal distribution and homogeneity of variance for the use of the parametric test (if confirmed, since two samples are compared, the t-test for independent samples is used). If the prerequisites are not met, the Mann-Whitney test is used, as this is the most commonly applied non-parametric test for two independent samples.

The Shapiro-Wilk test has been used to test normality, and is described in many papers as the most efficient normality test (e.g. Keskin 2006; Henderson 2006; Coin 2008). If the p-value is greater than the level of significance $(\alpha=0.05)$, it is concluded that there is no 
evidence that the population significantly deviates from the normally distributed population. In that case, it is advisable, before making a decision on the use of the t-test to test the homogeneity of variance using the F-test, because the effectiveness of the t-test also depends on the assumption that both samples derive from populations having the same variance.

Table 1: Statistical analysis related to unpruned speech rate.

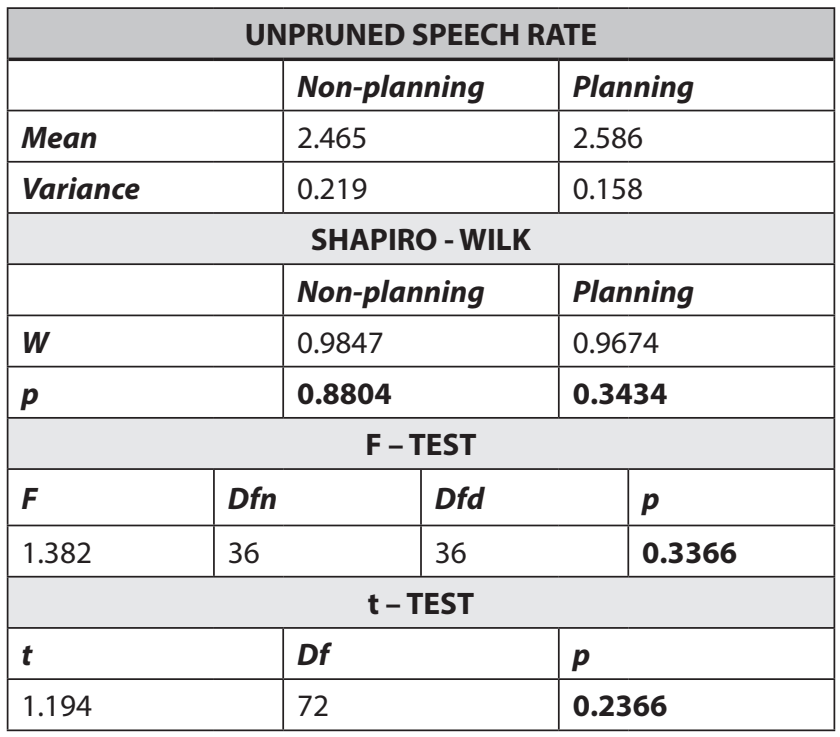

Table 2: Statistical analysis related to articulation rate.

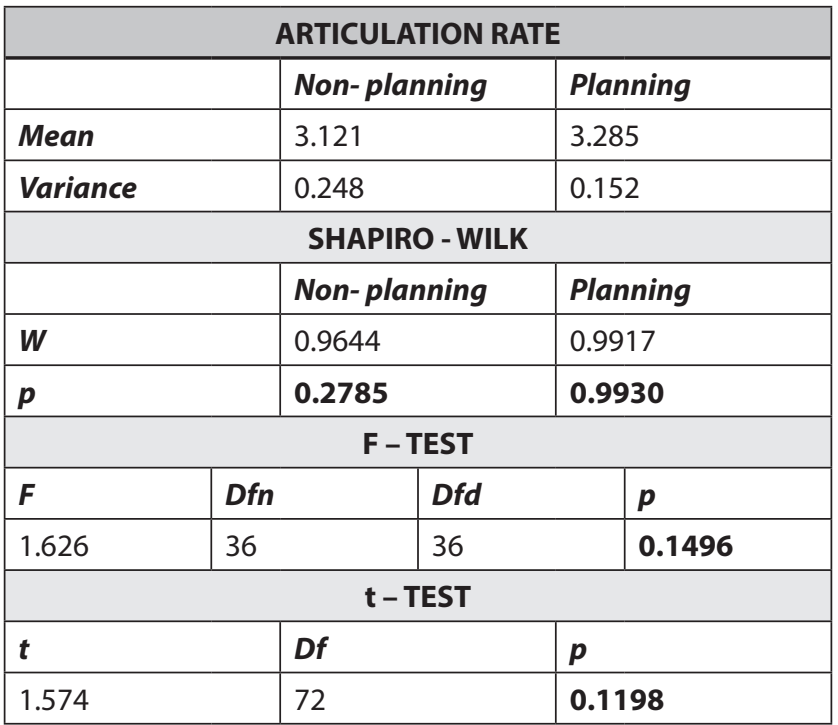


Tables 1 and 2 depict the results of the statistical analysis related to unpruned speech rate and articulation rate, representing speed fluency. The results indicate that there is not sufficient evidence about the existence of a significant difference between the planning and the non-planning population in the case of these two temporal measures.

According to the results of both the Shapiro-Wilk test and F-test, the number of pauses per minute (Table 3 ) is a breakdown fluency variable meeting the conditions for using the parametric t-test, which is therefore implemented. The second tested breakdown

Table 3: Statistical analysis related to number of pauses per minute.

\begin{tabular}{|c|c|c|c|c|}
\hline \multicolumn{5}{|c|}{ NUMBER OF PAUSES PER MINUTE } \\
\hline & & \multicolumn{2}{|c|}{ Non-planning } & Planning \\
\hline \multicolumn{2}{|l|}{ Mean } & \multicolumn{2}{|c|}{13.840} & 15.540 \\
\hline Variance & & \multicolumn{2}{|c|}{40.411} & 29.855 \\
\hline \multicolumn{5}{|c|}{ SHAPIRO - WILK } \\
\hline & & \multicolumn{2}{|c|}{ Non-planning } & Planning \\
\hline $\boldsymbol{W}$ & & \multicolumn{2}{|c|}{0.9662} & 0.9761 \\
\hline$p$ & & \multicolumn{2}{|c|}{0.3160} & 0.5956 \\
\hline \multicolumn{5}{|c|}{ F - TEST } \\
\hline $\boldsymbol{F}$ & \multicolumn{2}{|c|}{ Dfn } & Dfd & $p$ \\
\hline 1.353 & \multicolumn{2}{|c|}{36} & 36 & 0.3682 \\
\hline \multicolumn{5}{|c|}{$\mathbf{t}$ - TEST } \\
\hline $\boldsymbol{t}$ & & \multicolumn{2}{|c|}{ Df } & $p$ \\
\hline 1.240 & & \multicolumn{2}{|c|}{72} & 0.2191 \\
\hline
\end{tabular}

Table 4: Statistical analysis related to average pause duration.

\begin{tabular}{|c|c|c|}
\hline \multicolumn{3}{|c|}{ AVERAGE PAUSE DURATION } \\
\hline & Non-planning & Planning \\
\hline Mean & 0.921 & 0.805 \\
\hline Variance & 0.478 & 0.092 \\
\hline \multicolumn{3}{|c|}{ SHAPIRO - WILK } \\
\hline & Non-planning & Planning \\
\hline $\boldsymbol{W}$ & 0.4475 & 0.8169 \\
\hline$p$ & $<0.0001$ & $<0.0001$ \\
\hline \multicolumn{3}{|c|}{ MANN-WHITNEY TEST } \\
\hline \multicolumn{2}{|l|}{$\boldsymbol{U}$} & $p$ \\
\hline \multicolumn{2}{|l|}{595.0} & 0.3360 \\
\hline
\end{tabular}


fluency variable is the average pause duration (Table 4). Since it does not meet the prerequisites for using the t-test, the non-parametric Mann-Whitney test is utilized. Once again, no significant difference between the planning and non-planning populations is obtained.

The results obtained in this work are different than initially expected. It was hypothesized that the possibility to plan the story would have a significant impact on both the speech and articulation rates. The speech rate is largely determined by different forms of hesitations and pauses that are connected with the higher cognitive processes of speech production. On the other hand, the articulation rate or the speed of articulation movements requires a high degree of coordination between the various mechanisms involved in the control and execution of speech. Therefore, it was assumed that the planning time would influence both variables by reducing the processing pressure. The obtained results can be compared to Suzuki's findings (2017), based on his synthesis of previous research on pre-task planning. He claims that the results of six out of nine studies related to unpruned speech rate have not confirmed the existence of significant differences between the non-planning and planning populations. Therefore, the results gained in this study are consistent with those obtained in the majority of previous research. For instance, Yuan and Ellis (2003) have not verified that the pre-task planners are more fluent than the non-planners as far as the unpruned and pruned speech rates are concerned. Similarly, Chau (2014) has not found a significant difference between the two compared populations (i.e. the non-planners and the planners without the possibility of note taking). The data imply that it has not been proved that planning has a significant effect on the measured fluency variables. Hence, the proposed hypothesis has not been confirmed. It is to be emphasized that Suzuki (2017) points out that the number of studies confirming planning to be effective for fluency does not differ significantly from the number of those that find otherwise.

However, the results obtained for the breakdown fluency measures are as expected. In fact, Suzuki (2017) also takes into account a number of studies investigating the influence of planning on numerous breakdown fluency measures. In $44.44 \%$ of all analysed studies, the effectiveness of planning on breakdown fluency measures is not confirmed. For example, Foster and Skehan (1999) investigate the average number of pauses per 100 words and did not find significant differences between no-planning on the one hand and three types of planning on the other (solitary planning, teacher-fronted planning and group-based planning). Similarly, Chau (2014) reports no significant differences for the number of unfilled pauses per minute between the two compared populations, i.e. the non-planners and planners without the possibility of taking notes. 
The data obtained regarding all investigated variables may be explained by Levelt's model of speech production. The highly structured nature of the chosen task, the usage of high frequency lexemes, and the content's predictability might not impose significant cognitive demands on the level of conceptualization, and not cause substantial constraints related to the working memory. As a result, the content of the story represents no major effort in terms of discourse organization. Also, owing to the high level of automaticity of the speech encoding mechanisms, typical of advanced speakers, additional attention is available for monitoring, which is used by the speakers for checking the discourse level of their message. According to Levelt's model, the monitor or the speaker's own controlling device has two functions in speech production. Firstly, to compare the parsed aspects of inner and outer speech with the intended message, and secondly, to give instruction for the repair or modification of the propositional content of an utterance. As far as the formulation level is concerned, the selected lexemes might have reached a sufficient level of activation for lexical selection due to the frequency effect. In addition, the extra attentional resources made available by the automaticity of certain encoding processes have been directed to the level of formulation and articulation. As pointed out by Kormos (2006), advanced L2 speakers use the procedural knowledge of syntactic and morphological rules of language, which are automatically applied.

A clear structure and highly frequent lexemes presumably do not impose increased conscious attention on the part of the speaker, therefore, the formulation and articulation can, to a high degree, run in parallel. The provided interpretation is in line with the one presented by Kawauchi (2005), who assumes that speakers with good knowledge will benefit the least from planning, because they have already reached a certain level of linguistic knowledge allowing them to do well without it. In other words, the learners have internalized procedural knowledge of L2 linguistic features (Towell et al. 1996), or in terms of Segalowitz's distinction, they have gained L2 cognitive fluency, as reflected in utterance fluency, especially in the case of less demanding tasks where the required lexical units and grammatical forms are already primed.

The primary pedagogical goal of securing favourable conditions, such as pre-task planning, is to reduce the processing pressure due to the time constraints of real life communication. Though previous studies have considerably advanced our understanding of the role of pre-task planning on L2 performance, a slightly modified approach might reveal different outcomes. Therefore, we suggest that the criterion of lexical frequency could have a beneficial effect on the measured variables in the case of learners who have already reached a certain level of procedural knowledge. In order to further increase the speakers' fluency in terms of an automatic procedural skill, less recurrent vocabulary for highly frequent topics, as well as native-like phrases, should be included in the task design. The required vocabulary might be dealt with prior to the main task performance in the form of a rehearsal. This would provide learners with an opportunity to practice the task before the main performance through guided instruction. Beyond accelerating the 
retrieval of the required vocabulary, it may also support proceduralization. The main idea for introducing rehearsal with carefully guided instructions for the same task type is to help learners avoid potential lexical knowledge gaps. Moreover, procedural knowledge is much less likely to be forgotten than declarative knowledge, and thus more frequent usage of less common vocabulary will enable even the advanced learners to gradually extend their existing active repertoire and, consequently, improve fluency.

\section{CONCLUSION}

The study reported in this paper investigated the influence of pre-task planning on the different temporal fluency variables between the two groups of adult EFL speakers. It was assumed that the time allocated for planning would result in a more fluent speech in real time. By way of analogy, the absence of the planning opportunity would lead to more frequent breaks and a slower speech rate due to the simultaneous ongoing processes of speech production. The investigated temporal fluency variables were extracted by means of the PRAAT speech analysis program in order to automatically measure temporal variables for evaluation purposes. Fluency was operationalized as speed fluency (i.e. speech rate and articulation rate) and breakdown fluency (i.e. number of silent pauses per minute and average pause duration). The participants were instructed to respond to a narrative speech elicitation task including a picture description. The task contained a linear timeline, conventional content with a clear beginning, central part and conclusion, and a high degree of familiarity, implying that the general content of the story is part of the speakers' knowledge of the external and internal world.

The results obtained in this work do not verify the initial assumption that the possibility to plan before speaking has a significant influence on the temporal fluency measures investigated in the two groups. Thus, the hypothesis stating that planning will be associated with fluency gains has not been confirmed. The findings might suggest the following two conclusions. Firstly, the learners' knowledge might have reached a certain level of automatization of the speech encoding mechanisms, and secondly, the selected task did not impose significant cognitive demands. However, a definite answer to the question can only be obtained by means of a retrospective analysis and the participants' comments regarding the planning time. Overall, the interpretation of data and the resulting conclusions can be justified by Levelt's model of speech production, which represents the basis for the understanding of the influence of planning on the different speech performance variables.

Taking into account the results of this work, a slightly different approach is proposed relating to task design, based on the introduction of less recurrent vocabulary prior to the main task performance. The rehearsal of less frequent formulaic sequences will enable even the advanced learners to gradually extend their existing active repertoire. 


\section{BIBLIOGRAPHY}

BYGATE, Martin/Peter SKEHAN/Merrill SWAIN (eds.) (2001) Researching pedagogical tasks: Second language learning, teaching, and testing. London: Longman.

BYGATE, Martin/Virginia SAMUDA (2005) Integrative planning through the use of task repetition. R. Ellis (ed.), Planning and task performance in second language. Amsterdam: John Benjamins, 37-74.

CHAU, Hiep Thien (2014) The effects of planning with writing on the fluency, complexity, and accuracy of L2 oral narratives. East Lansing, Michigan: Michigan State University, Proquest Dissertations Publishing.

COIN, Daniele (2008) A goodness-of-fit test for normality based on polynomial regression. Computational Statistics and Data Analysis 52 (4), 2185-2198.

COUNCIL OF EUROPE (2001) Common European Framework of Reference for Languages: Learning, teaching, assessment. Cambridge: Cambridge University Press.

CUCCHIARINI, Catia/Helmer STRIK/Lou BOVES (2002) Quantitative assessment of second language learners' fluency by means of automatic speech recognition technology. Journal of the Acoustical Society of America 107 (2), 989-999.

DE JONG, Nivja/Margarita STEINEL/Arjen FLORIJN/Rob SCHOONEN/Jan HULSTIJN (2013) Linguistic skills and speaking fluency in a second language. Applied Psycholinguistics 34 (5), 893-916.

ELLIS, Rod (ed.) (2005) Planning and task performance in a second language. Amsterdam: John Benjamins.

ELLIS, Rod (2009) The differential effects of three types of task planning on the fluency, complexity, and accuracy in L2 oral production. Applied Linguistics 30 (4), 474-509.

FOSTER, Pauline/Peter SKEHAN (1996) The influence of planning and task type on second language performance. Studies in Second Language Acquisition 18 (3), 299-323.

FOSTER, Pauline/Peter SKEHAN (1999) The influence of source of planning and focus on planning on task-based performance. Language Teaching Research 3 (3), 215-247.

FOSTER, Pauline (2001) Rules and routines: A consideration of their role in the task based language production of native and non-native speakers. M. Bygate et al. (eds.), Researching Pedagogical Tasks: Second Language Learning, Teaching and Testing. Harlow: Pearson Education, 75-94.

FREED, Barbara (2000) Is fluency, like beauty, in the eyes (and ears) of the beholder? H. Riggenbach (ed.), Perspectives on fluency. Ann Arbor: University of Michigan Press, 243-265.

GÖTZ, Sandra (2013) Fluency in native and nonnative English speech. Amsterdam: John Benjamins. 
HENDERSON, Ralph (2006) Testing experimental data for univariate normality. Clinica Chimica Acta 366, 112-129.

KAWAUCHI, Chieko (2005) The effects of strategic planning on the oral narratives of learners with low and high intermediate L2 proficiency. R. Ellis (ed.), Planning and task performance in a second language. Amsterdam: John Benjamins, 143-164.

KESKIN, Siddik (2006) Comparison of several univariate normality tests regarding type I error rate and power of the test in simulation based small samples. Journal of Applied Science Research 2 (5), 296-300.

KORMOS, Judit (2006) Speech production and L2 acquisition. Mahwah, NJ: Lawrence Erlbaum.

KORMOS, Judit/Mariann DÉNES (2004) Exploring measures and perceptions of fluency in the speech of second language learners. System 32 (2), 145-164.

KOVAČ, Mirjana/Biljana MILATOVIĆ (2013) Analysis of Repair Distribution, Error Correction Rates and Repair Successfulness in L2. Studia Linguistica 67 (2), $225-255$.

KOVAČ, Mirjana (2016) The influence of task Type on Perceived Fluency. Studies in English Language Teaching 4 (2), 241-252.

LENNON, Paul (1990) Investigating fluency in EFL: A quantitative approach. Language Learning 40 (3), 387-417.

LEVELT, Willem (1989) Speaking. From Intention to Articulation. Cambridge, MA: MIT Press.

MEHNERT, Uta (1998) The effects of different lengths of time for planning on second language performance. Studies in Second Language Acquisition 20 (1), 83-108.

ORTEGA, Lourdes (1999) Planning and focus on form in L2 oral performance. Studies in Second Language Acquisition 21 (1), 109-148.

ORTEGA, Lourdes (2005) What do learners plan? Learner-driven attention to form during pretask planning. R. Ellis (ed.), Planning and task performance in a second language. Amsterdam: John Benjamins, 77-109.

POŽGAJ HADŽI, Vesna/Damir HORGA/Tatjana BALAZIC BULC (2012) Speech fluency: a result of oral language proficiency? Linguistica 52 (1), 87-100.

PREFONTAINE, Yvonne (2010) Differences in perceived fluency and utterance fluency across speech elicitation tasks: A pilot study. Papers from the Lancaster Postgraduate Conference in Linguistics and Language Teaching (LAEL PG) 5, 134-154.

RIAZANTSEVA, Anastasia (2001) Second language proficiency and pausing: A study of Russian speakers of English. Studies in Second Language Acquisition 23 (4), 497-526.

RIGGENBACH, Heidi (1991) Toward an understanding of fluency: A microanalysis of non-native speaker conversations. Discourse Process 14 (4), 423-441.

ROBINSON, Peter (2011) Task-based language learning: A review of issues. Language Learning 61 (s1), 1-36. 
SEGALOWITZ, Norman (2010) Cognitive bases of second language fluency. New York, NY: Routledge.

SEGALOWITZ, Norman (2016) Second language fluency and its underlying cognitive and social determinants. International review of Applied Linguistics 54 (2), 79-95.

SKEHAN, Peter (1996) Second language acquisition research and task-based instruction.

J. Willis and D. Willis (eds.), Challenge and change in language teaching. Oxford: Heinemann, 17-30.

SKEHAN, Peter (2003) Task based instruction. Language Teaching 36 (1), 1-14.

SKEHAN, Peter (2009) Modelling second language performance: Integrating complexity, accuracy, fluency and lexis. Applied Linguistics 30 (4), 510-532.

SKEHAN, Peter/Pauline FOSTER (1997) Task type and task processing conditions as influences on foreign language performance. Language Teaching Research 1 (3), 185-212.

SKEHAN, Peter/Bei XIAOYUE/Li QIAN/Zhan WANG (2012) The task is not enough: Processing approaches to task-based performance. Language Teaching Research 16 (2), 170-187.

SUZUKI, Mitsuko (2017) Complexity, accuracy, and fluency measures in oral pre-task planning: A synthesis. Second Language Studies 36 (1), 1-52.

TAVAKOLI Parveneh/Peter SKEHAN (2005) Strategic planning, task structure and performance testing. R. Ellis (ed.), Planning and task performance in a second language. Amsterdam: John Benjamins, 239-277.

TOWELL, Richard/Roger HAWKINS/Nives BAZERGUI (1996) The development of fluency in advanced learners of French. Applied linguistics 17 (1), 84-119.

VAN DEN BRANDEN, Kris (2006) Training teachers: Task-based as well? K. Van den Branden (ed.), Task-based language education: From theory to practice. Cambridge: Cambridge University Press, 217-273.

WANG, Zhan/Peter SKEHAN (2014) Structure, lexis, and time perspective: Influences on task performance. P. Skehan (ed.), Processing perspectives on task performance. Amsterdam: John Benjamins, 156-186.

WENDEL, John (1997) Planning and second language narrative production. Ph.D. dissertation. Japan: Temple University.

YUAN, Fangyuan/Rod ELLIS (2003) The effects of pre-task planning and on-line planning on fluency, complexity, and accuracy in L2 monologic oral production. Applied Linguistics 24 (1), 1-27. 


\section{POVZETEK}

\section{Vpliv načrtovanja na govorno hitrost in prekinitve govorne verige}

V raziskavi smo s pomočjo merjenja časovnih spremenljivk poskušali ugotoviti, kako načrtovanje vpliva na tekočnost govora pri govorcih drugega jezika. Udeleženci raziskave so bili študenti, ki smo jih razdelili v dve skupini po 37 oseb. Obe skupini sta morali opisati niz slik, pri čemer je imela ena skupina 10 minut časa za načrtovanje, druga pa je nalogo reševala brez predhodnega načrtovanja. Vrednosti časovnih spremenljivk tekočnosti govora smo izmerili s pomočjo programa za analizo govora PRAAT. Tekočnost govora določamo glede na hitrost (tj. hitrost govora in izgovora) in prekinitve govorne verige (tj. povprečno trajanje in število premorov). Iz rezultatov raziskave je razvidno, da načrtovanje reševanja naloge ne vpliva na posamezne časovne spremenljivke. Ti rezultati so verjetno posledica zasnove izhodiščne naloge, ki je napeljevala k rabi pogostih leksemov, zato pri govorcih z dobrim jezikovnim znanjem ni vplivala na povečano zbranost. To se je odražalo tudi pri izražanju in izgovorjavi. Glede na opisane rezultate predlagamo preoblikovanje izhodiščne naloge, tako da bo načrtovanje reševanja naloge govorca vodilo k rabi manj pogostih vzorcev namesto besedišča, ki se uporablja v vsakdanjih situacijah. Na ta način bo priprava na nalogo kot pedagoško sredstvo dobila jasen cilj, saj bo poskušala aktivirati manj pogosto besedišče, hkrati pa bo spodbujala najvišjo stopnjo tekočnosti govora.

Ključne besede: tekočnost govora, hitrost govora, prekinitev govorne verige, načrtovanje reševanja naloge, vodeno načrtovanje

\section{ABSTRACT}

The main purpose of this study is to investigate the effects of pre-task planning on L2 fluency performance by measuring the temporal variables. Performing a picture description task, two groups of thirty-seven students were given 10 minutes of planning time and no planning time before the performance, respectively. The temporal fluency variables are extracted by means of the PRAAT speech analysis program in order to be automatically measured for evaluation purposes. Fluency is operationalized as speed fluency (i.e. speech rate and articulation rate) and breakdown fluency (i.e. average pause duration and number of pauses). The results indicate that no significant difference is found when comparing the non-planning and planning condition for each temporal variable. Presumably, the chosen task type containing highly frequent lexemes does not seem to impose increased conscious attention on the part of the more proficient speakers, and thus the formulation and articulation can, to a high degree, run in parallel. Based on the observed results, a modified task design is proposed, i.e. guided pre-task planning directed to attend to less frequent formulae as vocabulary or lexical items for everyday contexts, having a clear potential as a pedagogic device, aiming at activating relatively underused vocabulary and promoting ultimate fluency in the temporal sense.

Keywords: utterance fluency, speed fluency, breakdown fluency, pre-task planning, guided planning 